\title{
Using the L\&D model in information support of educational process in Technical University
}

\author{
Litvinova M. ${ }^{\star}$, Shtanko 0. \\ Admiral Makarov National University of Shipbuilding, Kherson Branch, Kherson, Ukraine
}

Received: 29.07 .2020

Accepted: 25.09 .2020

\begin{abstract}
The paper considers the model "Learning \& Development" (L\&D), which during 2017-2020 was used and tested at the Energy Faculty of the Kherson Branch of the Admiral Makarov National University of Shipbuilding (KB NUS). An appropriate information environment has been created, in which six components of information support have been implemented. The practical tasks to be solved using the L\&D model are considered, the scheme of subjective access to information environment resources at different levels is developed and implemented in practice. In the educational process, the use of the traditional model of learning using PowerPoint, tutorials and handouts has been significantly reduced. Instead, there was a predominant use of internal (university) and general Internet systems, podcasts, interactive web-conferences, etc. Thanks to the introduction of the L\&D model, the problem of improving and optimizing information and analytical support for all specialties of the energy engineering faculty of KB NUS has been solved. The results of the application of the L\&D model in the educational process were studied in two areas: by expert assessment of the effectiveness of its impact on students' learning activities and by the results of employment of graduates. Based on the results of the expert evaluation, a comparison of learning outcomes in the experimental (EG) and control (CG) groups was performed on seven indicators. According to these indicators, the criterion score of the L\&D model was defined as "good" and "excellent". Comparative data on the success of training in the experimental and control groups show that the indicators of learning outcomes in the EG level of compliance with professional competencies is higher than in the $\mathrm{CG}$. It was found that $E G$ graduates are more in demand by employers than CG. The obtained positive result of the application of the L\&D model in the educational environment of the Technical University in Ukraine fully corresponds to the data of the application of such a model in vocational and business programs in Europe, America, Australia and others. Its use allows to improve the general level of computer and information support of all disciplines, to expand the computer and information competence of students, to increase the economic demand for graduates and to improve their employment.
\end{abstract}

Key words: model "Learning \& Development", information environment, learning success.

\section{Використання моделі L\&D в інформаційному забезпеченні освітнього процесу в технічному університеті}

\author{
Літвінова М. Б., Штанько О. Д. \\ Національний університет кораблебудування імені адмірала Макарова, Херсонська філія, Херсон, Україна
}

\begin{abstract}
Анотація. В роботі розглянуто модель "Learning \& Development" (L\&D), яку протягом 2017-2020 років було використано та апробовано на енерготехнічному факультеті Херсонської філії Національного університету кораблебудування імені адмірала Макарова (ХФ НУК). Створено відповідне інформаційне середовище, в якому реалізовано шість складових інформаційного забезпечення. Розглянуто практичні задачі, на вирішення яких спрямовано використання моделі L\&D, розроблено та реалізовано на практиці схему суб'єктного доступу до ресурсів інформаційного середовища на різних рівнях. У освітньому процесі суттєво скорочено застосування традиційної моделі навчання з використанням PowerPoint, навчальних посібників і роздаткового матеріалу. Замість цього відбувалося переважне використання внутрішньої (університетської) та загальної інтернет-систем, подкаст, інтерактивних wеb-конференцій та ін. Завдяки впровадженню моделі L\&D вирішено проблему покращення та оптимізації інформаційно-аналітичного забезпечення за всіма спеціальностями енерготехнічного факультету ХФ НУК. Результати застосування моделі L\&D у освітньому процесі було досліджено за двома напрямами: за експертною оцінкою ефективності її впливу на навчальну діяльність
\end{abstract}

Corresponding Author: Litvinova Maryna Borysivna. Tel. +380991718177. E-mail: Imb965@gmail.com. Kherson branch of Admiral Makarov National University of Shipbuilding, Ushakov av., 44, Kherson, Ukraine, 73000.

Biдповідальний автор: Літвінова Марина Борисівна. Тел. +380991718177 .E-mail: Imb965@gmail.com Херсонська філія Національного університету кораблебудування імені адмірала Макарова, просп. Ушакова, 44, м. Херсон, Україна, 73000. 
студентів і за результатами працевлаштування випускників. За результатами експертної оцінки було проведено порівняння результатів навчання в експериментальній (ЕГ) і контрольній (КГ) групах за сімома показниками. За цими показниками критеріальний бал застосування моделі L\&D був визначений як "добре" i "відмінно". Порівняльні дані успішності навчання в експериментальній та контрольній групах свідчать, що за показниками результатів навчання в ЕГ рівень відповідності фаховим компетентностям $€$ вищім, ніж у КГ. Встановлено, що випускники ЕГ є більш затребуваними з боку роботодавців, ніж КГ. Одержаний позитивний результат застосування моделі L\&D в освітньому середовищі технічного університету в Україні повністю відповідає даним застосування такої моделі в професійно-навчальних і бізнес програмах в Європі, Америці, Австралії та ін. ї̈ використання дозволяє покращити загальний рівень комп'ютерно-інформаційного забезпечення всіх дисциплін, розширити комп'ютерно-інформаційну компетентність студентів, підвищити економічний попит на випускників і покращити їх працевлаштування.

Ключові слова: модель "Learning \& Development", інформаційне середовище, успішність навчання.

\title{
Использование модели L\&D в информационном обеспечении образовательного процесса в техническом университете
}

\author{
Литвинова М. Б., Штанько А. Д. \\ Национальный университет кораблестроения имени адмирала Макарова, Херсонский филиал, Херсон, Украина
}

\begin{abstract}
Аннотация. В работе рассмотрена модель "Learning \& Development" (L\&D), которая в течение 2017-2020 годов была использована и апробирована на энерготехническом факультете Херсонского филиала Национального университета кораблестроения имени адмирала Макарова (ХФ НУК). Создана соответствующая информационная среда, в которой реализовано шесть составляющих информационного обеспечения. Рассмотрены практические задачи, на решение которых направлено использование модели L\&D, разработана и реализована на практике схема субъектного доступа к ресурсам информационной среды на разных уровнях. В образовательном процессе существенно сокращено применение традиционной модели обучения с использованием PowerPoint, учебных пособий и раздаточного материала. Вместо этого происходило преимущественное использование внутренней (университетской) и общей интернет-систем, подкаст, интерактивных web-конференций и др. Благодаря внедрению модели L\&D решена проблема улучшения и оптимизации информационно-аналитического обеспечения по всем специальностям энерготехнического факультета ХФ НУК. Результаты применения модели L\&D в образовательном процессе были исследованы по двум направлениям: по экспертной оценке эффективности ее влияния на учебную деятельность студентов и по результатам трудоустройства выпускников. По результатам экспертной оценки было проведено сравнение результатов обучения в экспериментальной (ЭГ) и контрольной (КГ) группах по семи показателям. По этим показателям критериальный балл применения модели L\&D был определен как "хорошо" и "отлично". Сравнительные данные успеваемости в экспериментальной и контрольной группах свидетельствуют, что по показателям результатов обучения в ЭГ уровень соответствия профессиональной компетентности является более высоким, чем в КГ. Установлено, что выпускники ЭГ более востребованными со стороны работодателей, чем КГ. Полученный положительный результат применения модели L\&D в образовательной среде технического университета в Украине полностью соответствует данным применения такой модели в профессионально-учебных и бизнес программах в Европе, Америке, Австралии и др. Её использование позволяет улучшить общий уровень компьютерно-информационного обеспечения всех дисциплин, расширить компьютерно-инфрормационную компетентность студентов, повысить экономический спрос на выпускников и улучшить их трудоустройства..
\end{abstract}

Ключевые слова: модель "Learning \& Development"), информационная среда, успешность обучения.

\section{Bcmyn}

Сучасні вимоги до оптимізації процесу накопичення та обробки інформації у високотехнологічному освітньому середовищі загалом та у середовищі технічного університету, зокрема, як було зазначено на Давоському форумі 2018 [1], вимагають пошуку нових інформаційнонасичених методів та засобів навчання. Останнім часом (особливо в умовах карантину) перебудова всій організації освітнього процесу розширила застосування електронного навчання разом із впровадженням інтерактивних web-конференцій та коучингу по телефону. Тобто має місце прискорене впровадження засобів комп'ютерно-інформаційного забезпечення та актуалізація задачі удосконалення та оптимізації методів і технологій їх застосування. Ї̈̈ вирішенню у межах компетентнісного підходу повністю відповідає нова освітня модель інформаційного забезпечення, яку за відповідною англомовною термінологією (Англія, Австралія, обмежено США) було названо як «Learning \& Development» або скорочено L\&D. Таким чином L\&D - термін, що позначає освітню функцію з головним 
акцентом на самостійне навчання, де відповідальність за результат більшою мірою лежить на плечах студента, ніж на плечах викладача [2].

Спочатку модель L\&D розроблялася та використовувалася під час корпоративного бізнеснавчання для його оптимального узгодження з бізнес-цілями та забезпечення ефективного задоволення потреб у навчанні та розвитку персоналу [3,4]. Проте складові L\&D, таки як лідерство, коучинг, цифрові рішення, комбіновані рішення не менш ефективно забезпечують і потреби організації навчального процесу у закладі вищої освіти та пошуку найкращих стратегій науково-дослідної роботи.

Вивченням даної теми в останні роки займалися і займаються багато вітчизняних і зарубіжних фрахівців з інфрормаційного забезпечення [5-9]. Зокрема, відбулося створення і використання адаптивних інтелектуальних моделей на основі комп'ютерно-інформаційних систем та Інтернету (від. англ. Adaptive and intelligent Web-based educational systems - AIWBES) [10], що забезпечують навчання спеціалістів для високотехнологічних галузей виробництва. Ці моделі становлять певну альтернативу для традиційного інформаційного підходу «просто виклади це в Інтернет». Наприклад, розповсюджені системи E-learning, найчастіше, важко використовувати. Їх застосування вимагає багато часу та зусиль, щоб проглянути і проаналізувати тисячі курсів та іншого навчального матеріалу для відбору того, що відповідає вузькій меті предметного навчання [11]. У освітній системі AIWBES намагаються бути більш адаптивними за допомогою побудови моделі цілей, переваг та індивідуалізованих знань, проте пошук актуальної інформації дуже часто обмежується фінансовими можливостями навчального закладу або студента особисто. Теж саме стосується інформаційного забезпечення таких напрямів як науководослідна діяльність та перспективи майбутнього працевлаштування випускників. Новій моделі інформаційного забезпечення L\&D призначено вирішити позначені проблеми.

Однак в українських закладах вищої освіти (3ВО), де у цілому ознайомлені 3 кращими ініціативами інформаційного забезпечення, що існують у моделі L\&D, по-перше, май же не знають про існуванням самої моделі як цілісного комплексу методів, а по-друге, в жодному ЗВО не проводилося відповідного наукового дослідження щодо впровадження даної моделі в освітній процес.

Meта роботи: дослідити ефрективність використання моделі L\&D в системі інформаційного забезпечення закладів вищої технічної освіти на прикладі Херсонської філії Національного університету кораблебудування імені адмірала Макарова (ХФ НУК).

\section{II Матеріали і методи дослідження}

Модель L\&D протягом 2017-2018, 2018-2019 та 2019-2020 навчальних років було використано та апробовано на енерготехнічному факультеті ХФ НУК. Херсонська фрілія з 1967 року є відокремленим підрозділом суднобудівного університету, що має IV рівень акредитації та забезпечує гнучку підготовку фахівців з кваліфікаційним рівнем бакалавр і магістр. Енерготехнічний факультет ХФ НУК сьогодні - це навчально-науково-виховний комплекс, здатний вирішувати будь-які питання професійної підготовки фахівців високої кваліфікації, чий рівень відповідає світовим вимогам.

Педагогічний експеримент проводився зі студентами, що здобували другий (магістерський) рівень вищої освіти за спеціальностями та освітніми програмами: 051 «Економіка» (освітньо-професійна програма (ОПП) «Економіка підприємства»,); 076 «Підприємництво, торгівля та біржова діяльність» (ОПП «Бізнес та приватне підприємство»); 135 «Суднобудування» (освітні програми: «Суднові енергетичні установки та устаткування», «Експлуатація, випробування та монтаж суднових енергетичних установок»,); 141 «Електротехніка, електроніка та електромеханіка» (ОПП «Експлуатація суднових автоматизованих систем»); 142 «Енергетичне машинобудування» (ОПП «Двигуни внутрішнього згоряння»); 144 «Теплоенергетика» (ОПП «Теплоенергетика», «Енергетичний менеджмент»).

Модель L\&D, яку застосовано підчас педагогічного експерименту, $є$ наріжним каменем будь-якої ефрективної інтелектуальної інформаційної системи, завдяки якій вирішувалася проблема покращення та оптимізації інфрормаційно-аналітичного забезпечення всіх зазначених дисциплін.

Практичні задачі, на вирішення яких було спрямовано використання моделі L\&D є такими:

1. Відповідно до моделі L\&D створити інформаційне середовище (IC) для:

- он-лайн підтримки і швидкого оновлення навчальних матеріалів; 
- оптимізованого пошуку фрахової інформації та даних з можливістю перегляду процесу пошуку, порівняння та оцінки одержаної інформації, виявлення прогалин в неї;

- ідентифікованого одержання інформації (через персональні кабінети);

- індивідуалізоване управління процесом організації інформації;

- синтезування нової інформації та даних для створення нових знань та їх поширення;

- здійснення ефективного фахового інформаційно-аналітичного забезпечення;

- організація взаємодії навчальної та науково-дослідної діяльності, що використовує "стратегічний" підхід, орієнтований на майбутню професійну діяльність студентів.

2. Реалізувати в IC наступні фуннкціональні вимоги відповідно до L\&D:

- простоту пошуку інформації;

- можливість працювати з великими масивами інфоомації, що щоденно поновлюється;

- швидкій доступ до необхідної інформації;

- стабільність інформації (неможливість її неконтрольованої зміни)

- конфіденційність доступу до інформації;

- безпека доступу до інформації.

3. Оптимізувати та спростити для майбутніх фрахівців пошук інформації, що забезпечує:

- постійний аналіз попиту спеціальностей Херсонської філії НУК на ринку праці;

- підтримку зв'язку з Державною службою зайнятості у Херсонської області;

- узгодження з підприємствами, установами та організаціями, незалежно від форм власності, які можуть бути потенційними роботодавцями, реальних потреб у молодих фахівцях за спеціальностями Херсонської фрілії НУК;

- інформування випускників, здобувачів вищої освіти Херсонської філії НУК про вакантні місця на підприємствах, в установках та організаціях, що відповідають їх фаховій підготовці для можливого працевлаштування;

- здійснення моніторингу працевлаштування випускників ХФ НУК;

- участь у регіональних програм Херсонського центру зайнятості, зокрема в проекті «Платформа державної служби зайнятості з профорієнтації та розвитку кар'єри»;

- знання щодо законодавчих та нормативно-правових актів з питань державного регулювання зайнятості та трудових відносин.

Схему, що ілюструє суб'єктний склад на різних рівнях доступу до ресурсів інформаційного середовища, надано на рисунку 1.

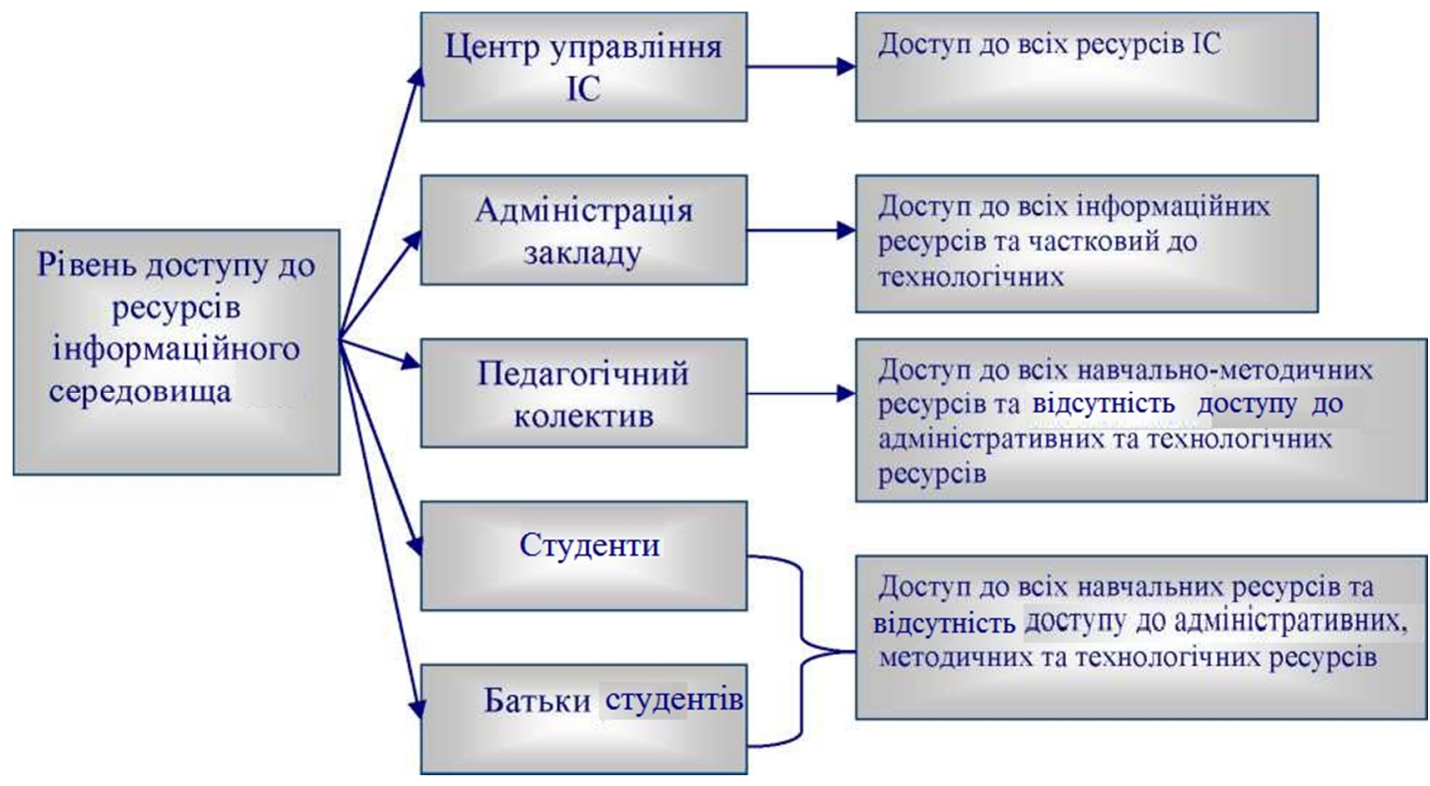

Рис. 1. Суб'єктний склад на різних рівнях доступу до ресурсів інформаційного середовища 
Для вирішення поставлених завдань було створено спеціальний відділ (центр управління IC на рис. 1), що забезпечує доступ до всіх ресурсів IC. Було створено відповідну посаду менеджера 3 управління знаннями та інтелектуальною власністю, що розробляє та надає за запитом студентів персональні синхронні та асинхронні навчальні модулі, забезпечує захист будь-яких оригінальних матеріалів і збереження власності, а також виключає можливість порушення авторських прав, здійснює перевірку на плагіат конкурсних, дипломних та інших робіт студентів i, по запиту, наукових робіт викладачів. Він також наглядає за зберіганням IT-даних, коректним форматуванням всього електронного навчального, наукового та іншого професійно-спрямованого матеріалу, його актуальністю, доступністю і можливістю передачі за запитом студента та викладача, консультує з проведення webпрезентацій на різних інтернет-платформах (включаючи управління web-камерою) та мультимедійних презентацій (включаючи створення відео та аудіо матеріалів). Окремим напрямом діяльності відділу $є$ інформаційне забезпечення науково-дослідних розробок, проведення аналізу їх перспективності та можливості впровадження, допомога в роботі з реферативними базами даних та відстеженні цитованості статей, опублікованих в наукових виданнях.

У межах IC було реалізовано шість складових інформаційного забезпечення:

1) створено електронну бібліотеку із структурованою системою інформації за фахом: створено окремий каталог контенту, що відповідає гнучким, сучасним фраховим ресурсам за дисциплінами, що вивчаються; проведено розділення й ранжування інформації; створено фаховий тезаурус, сформований на трьох мовах (української, англійської, російської);

2) створено методичне забезпечення для наповнення персональних електронних кабінетів;

3) застосований маркетинговий підхід до організації інформаційного поля, створено базу вакансій для майбутніх фахівців;

4) створено систему зворотного зв'язку, що надає можливість проведення ревізії та оцінки якості з боку студентів та викладачів спеціального освітнього програмного забезпечення; реалізований динамічний контроль того, який матеріал вивчається і як він застосовується на практиці; створено електронну систему контролю відвідування занять студентами;

5) реалізовані аналітичне планування та періодичний аналіз результатів діяльності студентів і викладачів;

6) створено системні перепони для використання плагіату та незаконного запозичені різних моделей та програм.

У освітньому процесі було суттєво скорочено застосування традиційної моделі навчання 3 використанням PowerPoint, навчальних посібників і роздаткового матеріалу. Відбувалося переважне використання внутрішньої (університетської) та загальної інтернет-систем, подкаст, інтерактивних webконференцій та ін. Програмне забезпечення відповідало третьому і четвертому рівням програмного обслуговування, кожний з яких має певні переваги. Третій рівень в якості послуги SaaS (Software-as a Service) $€$ найбільш пристосованим для застосування саме у освітній сфері. Підчас навчання у хмарному сервері зберігаються не тільки дані, а й пов'язані з ними програми. Викладачу лише необхідно мати доступ до веб-браузера для створення власних операційних систем і будь-яких додатків. Програмне забезпечення SaaS розраховане на викладача і студента. Воно забезпечує якісний сервіс, в межах якого відбувається швидкий доступ суб'єктів навчання до електронної пошти, різних операційних систем, прикладних програм і додатків. Усі сервіси забезпечують процес навчання завдяки спеціалізованими програмними засобами й обладнанням віддаленого доступу. Викладачу забезпечена можливість доступу до своїх даних за допомогою веб-браузера з будь-якого комп'ютера, приєднаного до мережі Інтернет. Студентами можуть використовуватися хмарні SaaS сервіси у вигляді: Webдодатків; електронних журналів і щоденників; різних он-лайн освітніх сервісів для здійснення спілкування, навчання, тестування; системи дистанційного навчання, бібліотеки; сховища фрайлів, спільного доступу; спільної роботи; електронної пошти з доменом закладу освіти [12]. Проте концепція SaaS має певні недоліки, головним з яких для освітнього процесу є те, що вона пристосована далеко не для всіх функціональних систем.

Цій недолік усунений на четвертому рівні поширення і експлуатації програмного забезпечення DaaS (Desktop as a Service) [13]. Такий рівень надає викладачу можливість створення стандартизованого віртуального робочого місця, яке налаштовується суб'єктом навчання для реалізації 
певних власних потреб. Підчас роботи відбувається доступ студента чи викладача не до окремого програмного продукту, а до програмного комплексу в цілому. На початку роботи користувачем за персональним кодом здійснюється аутентифікація і він може працювати з використанням потужностей віддаленого сервера, а не окремого ПК. Перевагами застосування DaaS є:

- можливість швидкої організації робочого місця з мінімальними початковими витратами;

- можливість доступу до повноцінного робочого місця за межами аудиторії;

- створення додатковий захисту основного масиву інформації;

- можливість динамічного контролю над потоками даних користувачів (студентів) з боку викладача.

Для реалізації проекту було застосовано новітні системи візуалізації 3D-об'єктів, сучасну версію технологіï SCORM (Sharable Content Object Reference Model - «зразкова модель об'єкта вмісту для спільного використання» - збірник специфікацій і стандартів, розроблений для систем дистанційного навчання), специфікації програм X-API (або Tin Can API). Крім функціонального удосконалення остання дозволяє враховувати види навчальної активності, недоступні в SCORM: забезпечення інформацією за допомогою мобільних пристроїв, ігри, симуляції, очне та змішане навчання. X-API надає можливість відстежувати всю цифрову діяльність, яка відбувається у навчальному процесі, тобто повністю відстежувати весь процес навчання. В декількох аудиторіях були встановлені відеокамери і система автоматичного розпізнавання обличчя студентів. Потім система здійснювала відповідні позначки в електронному журналі. Такий підхід економив час викладача і, найголовніше, робив контроль більш надійним.

У педагогічному експерименті приймали участь студенти, що навчалися в умовах використання моделі L\&D в інформаційному забезпеченні освітнього процесу (експериментальна група (ЕГ) загальною чисельністю 431 особа). Результати навчання ЕГ порівнювалися з результатами контрольної групи (КГ) студентів, що навчалися на енерготехнічному фракультеті за три попередніх роки до початку педагогічного експерименту (загальна чисельність 452 особи).

Результати застосування моделі L\&D у освітньому процесі ХФ НУК досліджувалася за двома напрямами: за експертною оцінкою ефективності ї̈ впливу на навчальну діяльність студентів і за результатами працевлаштування випускників.

Методика одержання критеріального балу експертної оцінки ґрунтуються на методиці, описаній у роботі [14]. За цією методикою спочатку відбувалося визначення показника значимості $S$ для кожної 3 шести позначених вище складових інформаційного забезпечення, що відображає, наскільки кожна складова $€$ ефрективною для підвищення якості навчання. Показник значимості встановлювався за експертною оцінкою за всіма освітніми програмами. В якості експертів було залучено найбільш досвідчені викладачі випускових кафедр ХФ НУК та провідних викладачів інших університетів, що викладали в магістратурі ХФ НУК за сумісництвом (таблиця 1).

Показник значимості $S$ заходився за формулою:

$$
S=\left(\sum_{i=1}^{k} x_{i}-k\right) / 4 k,
$$

де $k \in$ загальною кількістю експертів, $x_{i} \in$ оцінкою значимості, що надана $S_{i}$-тим експертом за п'ятибальною шкалою.

Для кожного показника, за методом, наданим у роботі [14], відбувалося визначення критеріального балу за чотирирівневою шкалою (негативно, задовільно, добре, відмінно) шляхом додавання показників значимості $S$ до середнього значення оцінки, виставленої експертами. Були визначені три критеріальних бали: $K_{61}<K_{62}<K_{63}$ :

- якщо за результатами експертної оцінки значення критеріального балу було менше, ніж $K_{61}$, то підсумкова оцінка була негативною;

- якщо більше (рівно) Кб1, але менше Кб2 - задовільною;

- більше (рівно) Кб2, але менше Кбз - доброю;

- більше (рівно) Кбз - відмінною. 
Табл. 1. Експерти, що залучені для встановлення значимості складових інформаційного забезпечення освітнього процесу

\begin{tabular}{|c|c|c|}
\hline № & Прізвище, науковий ступень та посада експерта & $\begin{array}{c}\text { Назва спеціальності випускової } \\
\text { кафедри }\end{array}$ \\
\hline 1 & $\begin{array}{l}\text { Андреєв А.А., к.Т.Н., зав. каф. суднового машинобудування та } \\
\text { енергетики ХФ НУК }\end{array}$ & $\begin{array}{l}142 \text { - Енергетичне } \\
\text { машинобудування }\end{array}$ \\
\hline 2 & $\begin{array}{l}\text { Баганов Є.О, к.т.н., зав. каф. енергетики, електротехніки і } \\
\text { фізики Херсонського національного технічного університету }\end{array}$ & $\begin{array}{l}141 \text { - Електроенергетика, } \\
\text { електротехніка та } \\
\text { електромеханіка }\end{array}$ \\
\hline 3 & $\begin{array}{l}\text { Гучек П.Й, Д.Т.н, зав. каф. інформаційних технологій та фріз-мат } \\
\text { дисциплін ХФ НУК }\end{array}$ & $\begin{array}{l}\text { 121- Інженерія програмного } \\
\text { забезпечення }\end{array}$ \\
\hline 3 & Джуринська А.О., к.т.Н., ст. викладач каф. теплотехніки ХФ НУК & 144 - Теплоенергетика \\
\hline 4 & $\begin{array}{l}\text { Дудченко О.М., к.т.н., декан суднобудівного факультету ХФ } \\
\text { НУК }\end{array}$ & $\begin{array}{l}\text { 121- Інженерія програмного } \\
\text { забезпечення }\end{array}$ \\
\hline 6 & $\begin{array}{l}\text { Коваленко В.Ф., д.ф.-м.н., професор кафедри інформаційно- } \\
\text { вимірювальних технологій електроніки та інженерії } \\
\text { Херсонського національного технічного університету }\end{array}$ & $\begin{array}{l}\text { 121- Інженерія програмного } \\
\text { забезпечення }\end{array}$ \\
\hline 7 & Коновалов Д.В., к.Т.н., зав. каф. теплотехніки ХФ НУК & 144 - Теплоенергетика \\
\hline 8 & 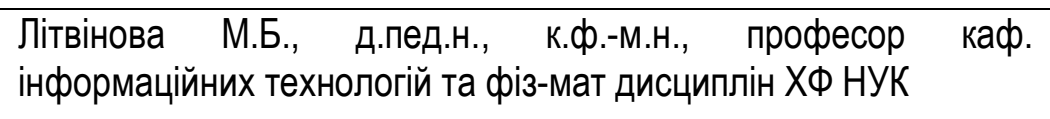 & $\begin{array}{l}\text { 121- Інженерія програмного } \\
\text { забезпечення }\end{array}$ \\
\hline 9 & Лугінін О.Є., к.Т.Н., професор каф. суднобудування ХФ НУК & 135 - Суднобудування \\
\hline 10 & $\begin{array}{l}\text { Політикін Б.М., д.Т.н., професор каф. інформаційних технологій } \\
\text { та фріз.-мат. дисциплін ХФ НУК }\end{array}$ & $\begin{array}{l}\text { 121- Інженерія програмного } \\
\text { забезпечення }\end{array}$ \\
\hline 11 & Руснак А.В., д.е.н., профресор каф. економіки ХФ НУК & 051 - Економіка \\
\hline 12 & $\begin{array}{lrrrr}\text { Савченко О.Г., } & \text { д.фр-м-н., професор каф. } \\
\text { математики та такладної } & \text { економічної } \\
\text { державернетики } & \text { Херсонського } \\
\text { деграрно-економічного уніварситету } & \end{array}$ & 051 - Економіка \\
\hline 13 & $\begin{array}{l}\text { Селіверстова С.Р., к.т.Н., доцент каф. експлуатації суднового } \\
\text { електрообладнання та засобів автоматики Херсонської } \\
\text { державної морської академії }\end{array}$ & $\begin{array}{l}\text { 141- Електроенергетика, } \\
\text { електротехніка та } \\
\text { електромеханіка }\end{array}$ \\
\hline 14 & $\begin{array}{l}\text { Уваров В.А. - к.Т.Н., доцент каф. суднового машинобудування } \\
\text { та енергетики ХФ НУК }\end{array}$ & $\begin{array}{l}142 \text { - Енергетичне } \\
\text { машинобудування }\end{array}$ \\
\hline 15 & $\begin{array}{l}\text { Штанько О.Д. к.ф-м.н., доцент каф. інформаційних технологій } \\
\text { та фріз-мат дисциплін ХФ НУК }\end{array}$ & $\begin{array}{l}\text { 121- Інженерія програмного } \\
\text { забезпечення }\end{array}$ \\
\hline 16 & Щедролосєв О.В., д.Т.н., зав. каф. суднобудування ХФ НУК & 135 - Суднобудування \\
\hline
\end{tabular}


Крім того, за результатами експертної оцінки відбувалося порівняння результатів навчання в експериментальній і контрольній групах. Експертна оцінка надавалася за сімома показниками:

1) відповідність знань теоретичного матеріалу вимогам фрахової компетентності;

2) уміння досліджувати та аналізувати експериментальні дані;

3) рівень володіння навичками самостійної роботи;

4) уміння реалізовувати набуті знання;

5) уміння, навички у інженерному моделюванні;

6) рівень інфрормаційної грамотності, навички використання Інтернет-ресурсу;

7) відповідність рівня засвоєння всього навчального матеріалу вимогам фахової компетентності.

Рівень відповідності за кожним показником визначався експертом у відсотках щодо рівня, визначеного фраховими компетентностями. Підсумковий відсоток знаходився, як середнє значення за оцінкою всіх експертів.

Показник результативності працевлаштування випускників за кожною освітньо-професійною програмою визначався як зміна відсотка працевлаштованих за спеціальністю випускників в експериментальній та контрольній групах.

\section{III Результати}

Навчання у сучасному закладі вищої освіти є немислимим без постійно діючого зворотного зв'язку, що інформує про стан освітнього процесу загалом і про якість його інформаційного забезпечення, зокрема. Відповідно, наведемо підсумкові результати педагогічного експерименту, що проводився за описаної у попередньому розділі методикою.

Результати експертного визначення критеріального балу (за чотирирівневою шкалою: негативно, задовільно, добре, відмінно) ефективності використання моделі L\&D в інформаційному забезпеченні освітнього процесу в ХФ НУК надано в таблиці 2 (оцінка відбувалася за освітньо-професійними програмами електромеханічного факультету).

Табл. 2. Критеріальний бал за експертною оцінкою

\begin{tabular}{|l|c|c|c|c|c|c|c|}
\hline \multirow{2}{*}{ ОПП } & \multicolumn{5}{|c|}{ Критеріальний бал відповідно до порядкового номеру показника } \\
\cline { 2 - 8 } & $\mathbf{1}$ & $\mathbf{2}$ & $\mathbf{3}$ & $\mathbf{4}$ & $\mathbf{5}$ & $\mathbf{6}$ & $\mathbf{7}$ \\
\hline $\begin{array}{l}\text { Суднові енергетичні } \\
\text { установки та устаткування }\end{array}$ & добре & добре & відмінно & добре & добре & добре & відмінно \\
\hline $\begin{array}{l}\text { Експлуатація, випробування } \\
\text { та монтаж суднових } \\
\text { енергетичних установок }\end{array}$ & відмінно & добре & відмінно & добре & відмінно & відмінно & добре \\
\hline $\begin{array}{l}\text { Двигуни внутрішнього } \\
\text { згоряння }\end{array}$ & добре & відмінно & добре & добре & добре & відмінно & добре \\
\hline $\begin{array}{l}\text { Холодильні машини та } \\
\text { установки }\end{array}$ & добре & добре & добре & відмінно & добре & добре & відмінно \\
\hline $\begin{array}{l}\text { Експлуатація суднових } \\
\text { автоматизованих систем }\end{array}$ & відмінно & добре & відмінно & добре & відмінно & добре & добре \\
\hline $\begin{array}{l}\text { Електромеханічні системи } \\
\text { автоматизації та } \\
\text { електропривод }\end{array}$ & добре & відмінно & добре & добре & відмінно & добре & відмінно \\
\hline $\begin{array}{l}\text { Економіка підприємства } \\
\text { Бізнес та приватне } \\
\text { підприємство }\end{array}$ & добре & добре & добре & відмінно & відмінно & добре & відмінно \\
\hline
\end{tabular}


Порівняльні дані успішності навчання в експериментальній та контрольній групах надано у таблиці 3 i, відповідно, на рисунку 2. Експертна оцінка надавалася за сімома показниками, наведеними у попередньому підрозділі.

Табл. 3. Результати експертного аналізу успішності педагогічного експерименту

\begin{tabular}{|c|c|c|c|c|c|c|c|}
\hline \multirow{3}{*}{ Група } & \multicolumn{7}{|c|}{ Рівень відповідності у відсотках за кожним показником } \\
\cline { 2 - 8 } & $\mathbf{1}$ & $\mathbf{2}$ & $\mathbf{3}$ & $\mathbf{4}$ & $\mathbf{5}$ & $\mathbf{6}$ & $\mathbf{7}$ \\
\hline $\mathrm{EГ}$ & 79 & 63 & 69 & 81 & 68 & 82 & 76 \\
\hline КГ & 68 & 47 & 48 & 76 & 55 & 69 & 65 \\
\hline
\end{tabular}

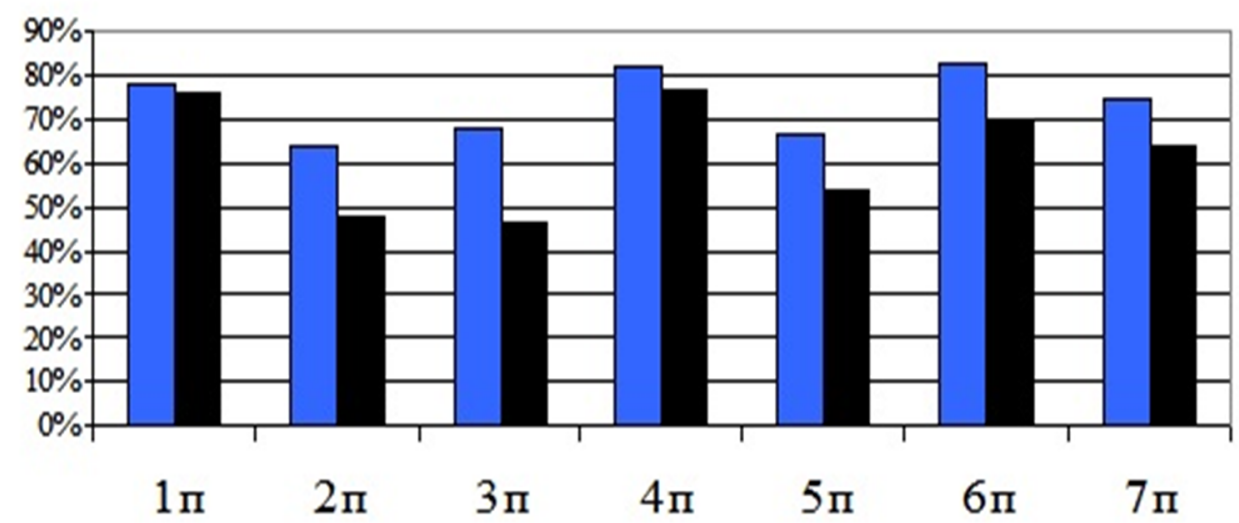

експериментальна група;

Рис. 2. Результати експертного аналізу успішності педагогічного експерименту (у відсотках до необхідного рівня) за сімома показниками

Порівняльні дані по відсотку працевлаштованих за випускників, що навчалися за освітньопрофесійними програмами енерготехнічного факультету в експериментальній та контрольній групах відображено в таблиці 4.

Табл. 4. Відсоток випускників, працевлаштованих за спеціальністю

\begin{tabular}{|l|c|c|c|}
\hline \multicolumn{1}{|c|}{ Освітньо-просресійна програма } & $\begin{array}{c}\text { КГ: разом 2015, } \\
2016,2017 \text { роки }\end{array}$ & $\begin{array}{c}\text { ЕГ: разом 2018, } \\
2019,2020 \text { роки }\end{array}$ & $\begin{array}{c}\text { 3мінсота } \\
\text { віда }\end{array}$ \\
\hline Суднові енергетичні установки та устаткування & 94 & 100 & +6 \\
\hline $\begin{array}{l}\text { Експлуатація, випробування та монтаж суднових } \\
\text { енергетичних установок }\end{array}$ & 82 & 92 & +10 \\
\hline Двигуни внутрішнього згоряння & 66 & 77 & +11 \\
\hline Холодильні машини та установки & 69 & 77 & +8 \\
\hline Експлуатація суднових автоматизованих систем & 89 & 100 & +6 \\
\hline Електромеханічні системи автоматизації та електропривод & 91 & 100 & +9 \\
\hline Економіка підприємства & 80 & 89 & +9 \\
\hline Бізнес та приватне підприємства & 89 & 100 & +11 \\
\hline У середньому за всіма ОПП & 81 & 89 & +9 \\
\hline
\end{tabular}


Одержані результати дозволяють провести якісний та кількісний аналіз ефективності використання моделі L\&D в системі інформаційного забезпечення в Херсонській філії Національного університету кораблебудування імені адмірала Макарова.

\section{IV Обговорення}

За даними таблиці 2 видно, що критеріальний бал, який виставлено експертами в результаті створення в освітньому середовищі ХФ НУК інформаційного середовища відповідно до моделі L\&D, за всіма показниками визначений як "добре" і "відмінно". Крім того, порівняльні дані успішності навчання в експериментальній та контрольній групах (табл. 3 і рис. 2) свідчать, що за показниками результатів навчання в ЕГ рівень відповідності фаховим компетентностям є вищім, ніж у КГ. Найбільш суттєве збільшення (майже на 20\%) відбулося за показником "рівень володіння навичками самостійної роботи", що $€$ дуже суттєвою компетенцією сучасного фахівця, яка забезпечує подальше професійне вдосконалення. Тому випускники стають більш затребуваними з боку роботодавців і на основі розвиненої інформаційної бази вакансій більш ефективно знаходять собі роботу за фахом. Про це свідчать дані таблиці 4, де відображено збільшення (у середньому на 9\%) відсотка працевлаштованих випускників експериментальної групі по відношенню контрольної групи.

Одержаний в нашому дослідженні позитивний результат застосування моделі L\&D в освітньому середовищі технічного університету в Україні повністю відповідає даним застосування такої моделі в професійно-навчальних і бізнес програмах в Європі, Америці, Австралії та ін. Найчастіше їі використання досліджувалося саме в бізнес сфері під час удосконалення навичок персоналу. Однак австралійським Інститутом навчання та розвитку (Australian Institute of Training and Development (AITD)) було також досліджено відповідну модель L\&D у контексти практики науково-дослідної роботи та використання її результатів [15], а малазійським Інститутом реалізації новітніх освітніх програм надані практичні рекомендації для подальшого розповсюдження даної моделі в освітньому середовищі [16]. На нашу думку до загальних висновків цих досліджень, що стосуються факторів впливу моделі L\&D на структуру інформаційного середовища, слід додати ті фрактори, що впливають на навчання і розвиток всередині самої освітньої організації а саме:

- стратегічні плани освітньої організації (університету) мають бути орієнтовані саме на майбутні потреби виробництва і бізнесу всіх видів і рівнів (малого, середнього, великого);

- інформаційна компетентність викладачів має постійно вдосконалюватися і стимулювати їх саморозвиток;

- необхідним є досягнення такого професійного рівня всіх викладачів, щоб їх навички передбачили зміни в виробництві та бізнесі (впровадження нових технологій, підвищення культури виробництва та ін.).

- всередині університетів мають бути створені спеціальні підрозділи, що забезпечують тісний зв'язок «корпоративний ланцюжок» між студентами-постачальниками професійних послуг і державними та приватними замовниками, відповідно до критерію "supply chain", розглянутому в роботі [17];

- має відбутися підвищення частки емпіричного навчання, заснованого на досвіді, пов'язаного 3 програмами з лідерства, управлінням проектами й інформаційним забезпеченням саморозвитку випускників, відповідно до критерію "ехреriential training", наданому в роботі [18].

- необхідною $є$ відповідність всієї наукової та науково-технічної продукції світовому рівню.

Як показує досвід нашого навчального закладу, для реалізації інформаційної моделі L\&D університет має забезпечувати і контролювати безперервне навчання всього викладацького складу, постійно створювати можливості для навчання всіх своїх працівників. Дуже важливим також $\epsilon$ створення спільного бачення серед працівників (викладачів) та керівників на перспективи розвитку навчального закладу, що згідно з дослідженнями $[19,20]$, забезпечує "есективне підключення працівників освітньої організації до її зовнішнього та внутрішнього середовища" (приклад відповідної інновації в освітньому процесі був описаний нами в роботі [21]). При цьому має забезпечуватися "стратегічне лідерство", яке вимагає здібності керівництва стратегічно мислити, динамічно корегувати навчальну та науково-дослідну діяльність відповідно до нових освітніх напрямків чи нових попитів на ринку праці. 
Таким чином, в нашому дослідженні успішно показано, що концептуальний виклик, що створюється стратегією моделі L\&D, забезпечує більш широкі можливості її застосування в освітньому просторі технічного університету. Оскільки різні освітні ссрери зберігають свою відмінність в організаційних умовах, виникає питання про те, як саме можна удосконалити модель L\&D для різних видів практики. Аналіз ефективності використання нової моделі інформаційного забезпечення за обраними в дослідженні показниками є плідним як для успішної роботи освітньої організації, так і для кар'єрного навчання персоналу у бізнес сфері, що забезпечує аналіз відповідності освітньої діяльності поточним потребам виробництва та аналіз відповідності інформаційних засобів і підготовленості студентів майбутнім потребам виробництва. Одержані результати можуть бути використані в інших 3ВО України.

\section{V Висновки}

у роботі досліджено ефрективність застосування моделі L\&D в системі інформаційного забезпечення закладу вищої технічної освіти на прикладі її використання в Херсонській фрілії Національного університету кораблебудування імені адмірала Макарова (ХФ НУК). У межах інформаційного середовища ХФ НУК було реалізовано шість складових інформаційного забезпечення, за впровадженням яких було здійснено експертну оцінку і визначено критеріальний бал за чотирирівневою шкалою. За результатами експертної оцінки проведено порівняння результатів навчання в експериментальній (ЕГ) і контрольній (КГ) групах за сімома показниками. Крім того, було здійснено порівняння результатів працевлаштування випускників ЕГ і КГ.

Встановлено, що за всіма показниками застосування моделі L\&D критеріальний бал був визначений як "добре" і "відмінно". Порівняльні дані успішності навчання в експериментальній та контрольній групах свідчать, що за показниками результатів навчання у ЕГ рівень відповідності фаховим компетентностям є вищім, ніж у КГ. Встановлено, що випускники ЕГ є більш затребуваними 3 боку роботодавців, ніж КГ.

3'ясовано, що до відомих раніше факторів впливу моделі L\&D на структуру інформаційного середовища слід додати фактори, які впливають на навчання і розвиток всередині самої освітньої організації.

Використання моделі L\&D в освітньому процесі дозволяє покращити загальний рівень комп'ютерно-інформаційного забезпечення всіх дисциплін, розширити комп'ютерно-інформаційну компетентність студентів, підвищити економічний попит на випускників і покращити їх працевлаштування.

\section{Бібліографрічні посилання}

1. Davos-Klosters. Shaping the Future of Education, Gender and Work: World Economic Forum Annual Meeting 2018, Switzerland. URL: http://www3.weforum.org/docs/WEF_Shaping_the_Future_of_Education_Gender_and_Work_2P_ 031116.pdf (дата звернення 07.06.2020).

2. Словарь HR-терминов. URL: https://hrbazaar.ru/glossary/ (дата звернення 12.06.2020).

3. Harrison R. Learning and Development. UK: CIPD Publishing, 2005. $141 \mathrm{p}$.

4. Learning and development Annual survey report. London, 2015. 42 p. URL: https://www.cipd.co.uk/Images/learningdevelopment_2015_tcm18-11298.pdf (дата звернення 19.06.2020).

5. Ящун Т. В., Громов Є. В., Сажко Г. І. Формування віртуального інфоормаційно-освітнього середовища на базі хмарних технологій: стан проблеми. Проблеми інженерно-педагогічної освіти (УІПА). Харків, 2015. Вип. 47. С. 110-116.

6. Литвинова С. Г. Проектування хмаро орієнтованого навчального середовища загальноосвітнього навчального закладу: монографрія. Київ: ЦП «Компринт», 2016. 354 с.

7. Трифонова О. М. Методична система розвитку інформаційно-цифрової компетентності майбутніх фрахівців компютерних технологій у навчанні фізики і технічних дисциплін у закладах вищої освіти: монографія. Кропивницький: ЦДПУ, 2019. 508 с.

8. Silky B., Sawtantar S., Kumar A. Use of Cloud Computing in Academic Institutions. IJCST. 2012. Vol. 3, Iss. 1. P. 427-429.

9. Vuorikari R., Punie Y., Carretero Gomez S., Vanden Brande G. DigComp 2.0: The Digital Competence Framework for Citizens. Update Phase 1: The Conceptual Reference Model. Luxembourg Publication Office of the European Union. EUR 27948 EN. 2016. 40 p. Doi:10.2791/11517/

10. Tzouveli P., Mylonas P., Kollias S. An intelligent e-learning system based on learner profiling and learning resources adaptation. Computers \& Education. 2008. Vol. 51, Iss. 1. P. 224-238. https://doi.org/10.1016/j.compedu.2007.05.005 
11. Özyurt Ö., Özyurt H., Baki A. Design and development of an innovative individualized adaptive and intelligent e-learning system for teaching-learning of probability unit: Details of UZWEBMAT. Expert Systems with Applications. 2013. Vol. 40, Iss. 8. P. 2914-2940. Doi: 10.1016/j.eswa.2012.12.008

12. Яценко В.В. Хмарні SAAS-сервіси в самостійній роботі з інформатики студентів економічних спеціальностей. Інформаційно-комунікаційні технології навчання: тези доповідей Всеукраїнської науково-практичної конференції (23 травня 2014 р.). Умань : ФОП Жовтий О. O., 2014. С. 123-125. URI: http://essuir.sumdu.edu.ua/handle/123456789/53142 (дата звернення 22.04.2020).

13. Huang Y-M. Examining students' continued use of desktop services: Perspectives from expectation-confirmation and social influence. Computers in Human Behavior. 2019. Vol. 96. P. 23-31. Doi:10.1016/j.chb.2019.02.010

14. Богданов І. Т. Методична система формування фрізико-технічних знань у процесі фахової підготовки майбутніх учителів фрізики: монографрія. Донецьк : Юго-Восток, 2009. 272 с.

15. Hodge S., Smith E., Barratt-Pugh L. Towards a Model of Learning and Development Practice. International Journal of HRD Practice, Policy and Research. 2016. Vol 1, No 2. P. 7-25. Doi: 10.22324/ijhrdppr.1.113

16. Surekha T. P., Shankar S., Sadashivegowda B. Enhancing the Quality of Engineering Learning through Skill Development for Feasible. Progress Procedia Computer Science. Part of special issue: 9th World Engineering Education Forum (WEEF 2019) Proceedings : Disruptive Engineering Education for Sustainable Development. 2020. Vol. 172. P. 128-133.

17. Semley N., Huang R., Dalton J. Feedback for Learning Development: Tourism students' perspective. Journal of Hospitality, Leisure, Sport \& Tourism Education. 2016. Vol. 19. P. 41-53. Doi: 10.1016/j.jhlste.2016.08.001

18. Nelwati, Abdullah K. L., Chan C. M., McKenna L. The effect of peer learning on professional competence development among Indonesian undergraduate nursing students. A quasi-experimental study. 2020. Vol. 36, Iss. 3. P. 99-176, A1-A4. Doi: 10.1016/j.profnurs.2020.03.008

19. Kemény Z., Beregi R., Tipary B., Abai K., Nacsa J. Recent advances in learning content and infrastructure development for layout and process planning courses at the SZTAKI learning factories. Procedia Manufacturing. 2020. Vol. 45. P. 319324. Doi.org/10.1016/j.promfg.2020.04.024

20. Abu Mansor N. N., Saidi M. I., Mohamed A., Idris N. Organizational Factors in Learning and Development Initiatives. Procedia - Social and Behavioral Sciences. 2012.Vol. 40. P. 565-570. Doi:10.1016/j.sbspro.2012.03.231

21. Litvinova M., Dudchenko O., Shtanko O., Karpova S. Using the experiment in the computer simulation training for prospecting software engineers. International Journal of Computing. 2020. Vol. 19, Iss. 2. P. 216-223. URL: https://www.computingonline.net/computing/article/view/1764

\section{References}

1. Davos-Klosters, "Shaping the Future of Education, Gender and Work": World Economic Forum Annual Meeting 2018, Switzerland. URL: http://www3.weforum.org/docs/WEF_Shaping_the_Future_of_Education_Gender_and_Work_2P_ 031116.pdf (accessed 07.06.2020).

2. Slovar' HR-terminov.URL: https://hrbazaar.ru/glossary/ (accessed 12.06.2020). [in Russian]

3. Harrison R. (2005). Learning and Development. UK: CIPD Publishing, $141 \mathrm{p}$.

4. Learning and development Annual survey report. (2015). London, 42 p. URL: https://www.cipd.co.uk/lmages/learningdevelopment_2015_tcm18-11298.pdf (accessed 19.06.2020).

5. Yashchun, T. V., Hromov, Ye. V., Sazhko, H. I. (2015). Formuvannya virtual'noho informatsiyno-osvitn'oho seredovyshcha na bazi khmarnykh tekhnolohiy: stan problemy. Problemy inzhenerno-pedahohichnoyi osvity (UIPA). Kharkiv, 47, 110-116. [in Ukrainian]

6. Lytvynova, S. H. (2016). Proektuvannya khmaro oriyentovanoho navchal'noho seredovyshcha zahal'noosvitn'oho navchal'noho zakladu: monohrafiya. Kyyiv: TSP «Komprynt», 354 p. [in Ukrainian]

7. Tryfonova, O. M. (2019). Metodychna systema rozvytku informatsiyno-tsyfrovoyi kompetentnosti maybutnikh fakhivtsiv komp"yuternykh tekhnolohiy u navchanni fizyky i tekhnichnykh dystsyplin u zakladakh vyshchoyi osvity: monohrafiya. Kropyvnyts'kyy, 508 p. [in Ukrainian]

8. Silky, B., Sawtantar, S., Kumar, A. (2012). Use of Cloud Computing in Academic Institutions. IJCST, 3 (1), $427-429$.

9. Vuorikari, R., Punie, Y., Carretero Gomez, S., Vanden Brande, G. (2016). DigComp 2.0 : The Digital Competence Framework for Citizens. Update Phase 1: The Conceptual Reference Model. Luxembourg Publication Office of the European Union. EUR 27948 EN, 40 p. Doi: 10.2791/11517/

10. Tzouveli, P., Mylonas, P., Kollias, S. (2008). An intelligent e-learning system based on learner profiling and learning resources adaptation. Computers \& Education, 51 (1), 224-238. https://doi.org/10.1016/j.compedu.2007.05.005

11. Özyurt, Ö., Özyurt, H., Baki, A. (2013). Design and development of an innovative individualized adaptive and intelligent elearning system for teaching-learning of probability unit: Details of UZWEBMAT. Expert Systems with Applications, 40 (8), 2914-2940. Doi: 10.1016/j.eswa.2012.12.008

12. Yatsenko, V. V. (2014). Khmarni SAAS-servisy v samostiyniy roboti z informatyky studentiv ekonomichnykh spetsial'nostey. Informatsiyno-komunikatsiyni tekhnolohiyi navchannya: tezy dopovidey Vseukrayins'koyi naukovo-praktychnoyi konferentsiyi (23 travnya 2014), 123-125. URl: http://essuir.sumdu.edu.ua/handle/123456789/53142 [in Ukrainian]

13. Huang, Y-M.(2019). Examining students' continued use of desktop services: Perspectives from expectation-confirmation and social influence. Computers in Human Behavior, 96, 23-31. Doi:10.1016/j.chb.2019.02.010 
14. Bohdanov, I. T. (2009). Metodychna systema formuvannya fizyko-tekhnichnykh znan' u protsesi fakhovoyi pidhotovky maybutnikh uchyteliv fizyky: monohrafiya. Donets'k : Yuho-Vostok,2009. 272 c. [in Ukrainian]

15. Hodge, S., Smith, E., Barratt-Pugh, L. (2016). Towards a Model of Learning and Development Practice. International Journal of HRD Practice, Policy and Research, 1 (2), 7-25. Doi: 10.22324/ijhrdppr.1.113

16. Surekha, T. P., Shankar, S., Sadashivegowda, B. (2020). Enhancing the Quality of Engineering Learning through Skill Development for Feasible. Progress Procedia Computer Science. Part of special issue: 9th World Engineering Education Forum (WEEF 2019) Proceedings : Disruptive Engineering Education for Sustainable Development, 172, 128-133.

17. Semley, N., Huang, R., Dalton, J. (2016). Feedback for Learning Development: Tourism students' perspective. Journal of Hospitality, Leisure, Sport \& Tourism Education, 19, 41-53. Doi: 10.1016/j.jhlste.2016.08.001

18. Nelwati, Abdullah, K. L., Chan, C. M., McKenna, L. (2020). The effect of peer learning on professional competence development among Indonesian undergraduate nursing students. A quasi-experimental study, 36 (3), 99-176, A1-A4. Doi: 10.1016/j.profnurs.2020.03.008

19. Kemény, Z., Beregi, R., Tipary, B., Abai, K., Nacsa, J. (2020). Recent advances in learning content and infrastructure development for layout and process planning courses at the SZTAKI learning factories. Procedia Manufacturing, 45, 319324. Doi.org/10.1016/j.promfg.2020.04.024

20. Abu Mansor, N. N., Saidi, M. I., Mohamed, A., Idris, N. (2012). Organizational Factors in Learning and Development Initiatives. Procedia - Social and Behavioral Sciences, 40, 565-570. Doi:10.1016/j.sbspro.2012.03.231

21. Litvinova, M., Dudchenko, O., Shtanko, O., Karpova, S. (2020). Using the experiment in the computer simulation training for prospecting software engineers. International Journal of Computing, 19 (2), 216-223.

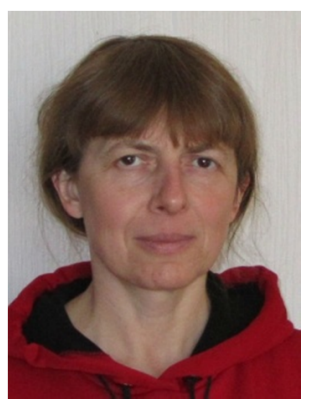

\section{Літвінова Марина Борисівна,}

д-р пед. наук, канд. фіз.-мат. наук, професор каф. інформаційних технологій та фіз.-мат. дисциплін, Херсонська філія Національного університету кораблебудування імені адмірала Макарова, просп. Ушакова, 44, м. Херсон, Україна, 73000.

Тел. +380991718177 . E-mail: Imb965@gmail.com

\section{Litvinova Maryna Borysivna,}

Doctor in Pedagogy, PhD in Physics and Mathematics, Professor of Department of Software Engineering, Physics and Mathematics, Kherson branch of Admiral Makarov National University of Shipbuilding,

Ushakov av., 44, Kherson, Ukraine, 73000.

Tel. +380991718177. E-mail: Imb965@gmail.com

ORCID: https://orcid.org/0000-0002-4917-2132

Researcher ID: AAD-6681-2019

Scopus ID: 55937925000

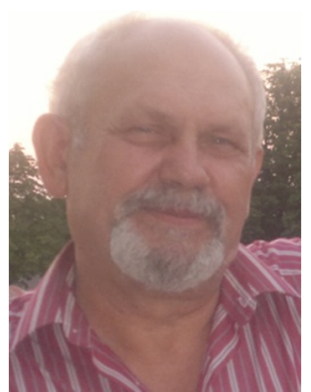

\section{Штанько Олександр Дмитрович.}

канд. фіз.-мат. наук, доцент каф. інфформаційних технологій та фіз.-мат. дисциплін,

Херсонська філія Національного університету кораблебудування імені адмірала Макарова,

Просп. Ушакова, 44, м. Херсон, Україна, 73000.

Тел. +380661752326. E-mail: sadmar954@gmail.com

\section{Shtanko Olexandr Dmytrovych.}

PhD in Physics and Mathematics, Associate Professor of Department of Software Engineering, Physics and Mathematics, Kherson branch of Admiral Makarov National University of Shipbuilding,

Ushakov av., 44, Kherson, Ukraine, 73000.

Tel. +380661752326 . E-mail: sadmar954@gmail.com

ORCID: https://orcid.org/0000-0003-3572-7915

Scopus ID: 8707692200

\section{Citation (APA):}

Litvinova M., Shtanko O. (2020). Using the L\&D model in information support of educational process in Technical University. Engineering and Educational Technologies, 8 (3), 45-57. doi: https://doi.org/10.30929/2307-9770.2020.08.03.04

\section{Цитування (ДСТУ 8302:2015):}

Літвінова М. Б., Штанько О. Д. Використання моделі L\&D в інфрормаційному забезпеченні освітнього процесу в технічному університеті / Інженерні та освітні технології. 2020. Т. 8. № 3. С. 45-57. doi: https://doi.org/10.30929/2307-9770.2020.08.03.04

Обсяг статmі: сторінок-13 ; умовних друк. аркушів - 1,883. 